\title{
Prediking aan die hand van die metafoor van fiksieskryf
}

\author{
Lourens Bosman \& Julian Müller \\ Department Praktiese Teologie \\ Universiteit van Pretoria
}

\begin{abstract}
Preaching according to the metaphor of fiction writing

In this article the writers propose an alternative to modernistic linear and propositional ways of preaching. They argue that the context asks for preaching that is more in line with the dominant metaphors of the post-modern culture in which the listeners live their everyday lives. The preacher should be seen less as the bearer of final truths (the one who carries the light or acts as witness to the truth), and more as someone who participates in the reflection of ideas. They propose a narrative paradigm for preaching that moves beyond the use of stories as illustrations, to one where the preacher, in the narrative style, becomes the co-author of new life stories in the preaching event. The ABDCE model for fiction writing, proposed by Anne Lamott, is then used as a model for the structuring of the sermon. Structured along these lines, the sermon moves from a specific Action and its cultural and historical Background, through a Development, where something new starts to unfold before the listeners, to a Climax of new insight and an Ending that invites the listeners to take part in the telling and retelling of their own stories in the light of the Great Story of God and his people.
\end{abstract}

\section{PREDIKING - WAT IS DIE PROBLEEM?}

Elke Sondag moet daar gepreek word in 'n konteks waar die omgewing al hoe meer en al duideliker postmodern word, terwyl die situasie binne die kerk steeds sterk modernistiese en selfs pre-moderne trekke vertoon. Die vraag wat ons in hierdie artikel wil aanspreek, is oor hoe ons vir postmoderne mense kan preek? Ons is van mening dat postmoderne mense beter aangespreek word deur 'n preek wat in die narratiewe styl voorberei en aangebied word as deur prediking in die vorm van proposisies.

Ten aanvang wil ons aansluit by drie metafore wat Kearney (1998:253) ontwikkel om die verandering te verduidelik wat plaasvind ten opsigte van die 


\section{Prediking aan die hand van die metafoor van fiksieskryf}

siening van die self en waarheid. In die pre-moderne paradigma kan die dominante metafoor verstaan word aan die hand van 'n spieël wat die lig uit 'n transendente oorsprong weerkaats, terwyl die moderne paradigma uitgedruk word met die metafoor van ' $n$ lamp wat ' $n$ eie, oorspronklike lig binne die self na buite homself projekteer. Die postmoderne paradigma daarenteen, kan die beste beskryf word met die metafoor van 'n meervoudige doolhof van beelde soos van spieëls wat mekaar reflekteer en waar dit onmoontlik is om die oorspronklike beeld te vind. "The postmodern paradigm is, in other words, that of a labyrinth of mirrors which extend infinitely in all directions - a labyrinth where the image of the self (as a presence to itself) dissolves into self-parody" (Kearney 1998:253).

Hierdie parodie, of speelse refleksie op die werklikheid en die self, word die kenmerk van die postmoderne. Die mense wat Sondae in die kerk sit, is deurdrenk met hierdie paradigma van meervoudige beelde en perspektiewe. Hulle word daarin gedoop deur hulle blootstelling aan films, nuusprogramme, die skilderkuns en letterkunde. Kearney (1998:253) sê: "The parodic paradigm recurs time and again in postmodern works of art and literature." Die vraag is nou hoe daar homileties op hierdie werklikheid gerespondeer word?

Een moontlike reaksie is om eenvoudig aan die hand van die metafore van die lamp en die spieël, met groter lineêre gesag te preek. 'n Goeie voorbeeld is 'n proefskrif wat in Februarie 2007 by die Fakulteit Teologie, Universiteit van Pretoria, verdedig is. In die proefskrif word 'n keuse gemaak teen die fokus op "human experience", vir "the proclamation of the glory of God". Daarmee is predikers steeds "suksesvol". Dit is die soort taal wat kerkgangers graag hoor. De Kiewit (2007:137) rapporteer dat ongeveer 63\% van respondente wat aan die "expository" model van prediking blootgestel is, dit verkies. Of dit hulle egter wesenlik beïnvloed, is ' $n$ ander vraag.

'n Verdere vraag wat oor hierdie soort navorsing gevra moet word, is oor die "mark" onder wie die navorsing gedoen is en op wie die prediking gerig word. Alhoewel dit vreemd mag aandoen om in die teologie en kerk van 'n mark te praat, word daar sedert die seminale Knowledge and human interest van Jürgen Habermas (1968:307-311) al hoe wyer erken dat alle kennis vir een of ander mark geproduseer word. Jackelén (2003:213-214) is van mening dat dit nodig is om baie krities te kyk na die invloed van die mark op wetenskap en godsdiens. "... it is obvious that science and religion are also subject to the economic forces governing the societies in which these activities are pursued." Dit sou dan inhou dat mens tog krities moet omgaan met navorsing binne die kerk oor preekvoorkeure. 'n Baie bepaalde deel van die mark word hier uitgelig. (Onder wie het hy sy navorsing gedoen? Wat is 
die ouderdomsprofiele? Wat is hulle kerklike betrokkenheid?) In 'n tyd waarin hoofstroomkerke wêreldwyd aan die krimp is, behoort 'n soeke na maniere om die kultuurgaping wat bestaan tussen gereelde en ingewyde erediensgangers en diegene wat van die kerk vervreem geraak het, te oorbrug, hoog op die agenda van nadenke oor die prediking te wees. Proposisionele, teksverklarende (expository) prediking is dikwels net toeganklik vir mense wat reeds ingewydes is in die kerklike taal en vorm waarin die preek aangebied word.

In hierdie verband dui Gibbs en Bolger (2006:70-71) twee groot skuiwe aan wat plaasgevind het van die modernisme na die postmoderne era ten opsigte van die wyse van kommunikasie. Eerstens is daar die skuif weg van die lineêre kommunikasie van abstrakte, proposisionele waarhede na konkrete, veelfasettige narratiewe met meervoudige betekenis. Verder is daar ook 'n skuif weg van die enkelvoudige klem op luister na die dominansie van visuele kommunikasie. Prediking vind vandag plaas in 'n visuele en storiegedrewe kultuur. Dit is ook beter in lyn met die herontdekking van die Bybel as 'n kompleks van narratiewe, en staan teenoor "“... the evangelical churches' way of reading the Bible as a singular book with one voice rather that as a book with many voices and many ways of interpreting'" (Rollins, soos aangehaal deur Gibbs \& Bolger 2006:70).

Postmoderne navorsing in die kommunikasiewetenskap (Mumby 1997:16-17) ondersoek onder andere die wyses waarop kommunikasie geresepteer word en dan spesifiek die reaksie op kommunikasie wat op outoritêre wyse "van bo af" kom. Alhoewel dit op die oog af mag lyk of mense hulleself aan sodanige outoritêre kommunikasie onderwerp, bied gemarginaliseerde groepe op allerlei maniere weerstand daarteen deur dit op subtiele en kreatiewe wyses te herinterpreteer en alternatiewe diskoerse daarteenoor te ontwikkel. Postmoderne nadenke oor kommunikasie toon die kwesbaarheid van dominante sisteme van kommunikasie aan. Alhoewel dit mag lyk asof kommunikasie wat met groot gesag beklee is ' $n$ bepaalde werklikheid mag versadig, toon postmoderne navorsers aan dat dit weerstand en alternatiewe interpretasies uitlok.

Hiermee saam gaan die versigtigheid en selfs weerstand wat daar in postmoderne kulture bestaan teen 'n outoritêre styl van leierskap wat in bepaalde gemeenskappe groot skade aangerig het omdat dit op mense afgedwing is ( $\mathrm{Nel} 2001: 56$ ). Ten opsigte van prediking beteken dit dat mens nie te seker moet wees dat 'n outoritêre styl van prediking noodwendig die boodskap die beste oordra nie. Dit mag wees dat dit subtiele vorme van weerstand uitlok en in elk geval op totaal alternatiewe maniere herinterpreteer word. 


\section{Prediking aan die hand van die metafoor van fiksieskryf}

Daarom is ons van mening dat ' $n$ reaksie op die uitdagings van die postmoderne era eerder gebaseer moet word op die dominante paradigma in die kultuur as op die gangbare kommunikasievorm binne die kerk. Die mense wat in die kerk sit en luister na 'n preek, se koppe is, by wyse van spreke, vol meervoudige beelde en perspektiewe wat mekaar weerkaats. Die konsepte en beelde waarin die preek na hulle toe kom, word deel van 'n dinamiese uitruil van idees. Die prediker is nie meer net die een wat die "lamp" gesagvol omhoog hou en koers aandui nie. Hy/sy is eerder deel van die parodie van die lewe. Daar hoef nie meer ' $n$ finale uitkoms te wees met 'n absolute waarheid wat uit die preek spreek nie. Dit word eerder gemaklik opgeneem in 'n wêreld van paradokse waar idees (speels) heen en weer gekaats word.

'n Narratiewe manier van preek wat minder outoritêr en meer insluitend en uitnodigend is, bied onses insiens meer gepaste moontlikhede en sluit meer verantwoordelik aan by die huidige paradigma: "Omdat ' $n$ narratiewe benadering nie op 'n eksklusiewe wyse werk nie, nooi dit mense uit om hulle eie geloofsverhale dikker te beskryf, om hulleself in te sluit in die groot geloofsverhale, eerder as dat dit veroordelend en uitsluitend werk, wat lei tot dunner beskrywings van die eie geloofsverhale." (Bosman 2001:285)

\subsection{Homiletiese posisionering}

In hierdie artikel posisioneer ons onsself in die breë stroom wat dikwels beskryf word as die Nuwe Homiletiek wat in die laaste kwart van die $20^{\mathrm{e}}$ eeu sterk na vore kom. Immink (2004:100-101) beskryf die hoofkenmerk van hierdie beweging soos volg:

... preaching must be understood as an event in time. The purpose of preaching is not to transmit cognitions, but to facilitate an event to be experienced. (...) ... a more traditional assertive discourse is renounced, and a more indicative, narrative, and imaginative way of speaking is welcomed.

Die voorstel wat hier gemaak word, moet verstaan word binne die paradigma van 'n narratiewe benadering, maar dan op 'n meer fundamentele wyse verstaan as wat narratiewe gewoonlik in die Nuwe Homiletiek gesien word. Dit is om hierdie rede dat ons wonder of Long (2005:19-45) se hantering van die vier beelde vir die prediker, die herald, die pastor en die storyteller/poet en sy keuse vir witness die beste oplossing is. Hy skryf pragtig en propageer die beeld van witness (wat ook die titel van sy boek is) met oortuiging. Die vraag is egter of hy daarmee die slaggat van die modernistiese paradigma vermy? Sy benadering word moontlik nog ' $n$ voorbeeld van 'n homiletiese benadering wat in 'n postmoderne tyd die modernistiese preekstyl goed afstof, 'n paar 
veranderinge aanbring en dit dan aanbied as antwoord vir die toekoms. 'n Winspunt van hierdie beeld is dat dit die waarheidsaansprake van die prediking beter kontekstualiseer as die ander, maar die beeld van die getuie ontsnap ongelukkig nie geheel aan die modernistiese lamp-metafoor nie. Inherent aan die beeld van die getuie is dat dit iemand is wat die lig gesien het en wat met sy getuienis die waarheid kan laat seëvier. Long (2005:49) sê: "The preacher explores the Scripture, faithfully expecting to discover the truth of God's claim there (...) (and) when the claims of God through the Scripture are seen and heard, the preacher turns back toward those who wait - and tells the truth." So 'n siening van "die waarheid" wat aan die wagtende gemeente oorgedra word, is tipies van modernistiese prediking wat gekenmerk word deur lineêre en proposisionele kommunikasie. Dit werk miskien goed vir ingewyde erediensgangers, maar verg 'n groot kultuursprong vir mense wat gewoond is aan die gangbare vorme van kommunikasie in 'n postmoderne kultuur.

Long is oop vir die narratiewe benadering as deel van die taak van die witness. Hy sê (2005:49): "Most often the witness is invited to 'tell your story'; thus the prominence given to narrative in the storytelling image is also implied in the image of witness." Ons verstaan van 'n narratiewe benadering moet egter gesien word as voortspruitend uit 'n narratiewe paradigma wat veel meer inhou as die benutting van narratiewe tegnieke of die vertel van 'n paar verhale in die oordra van die evangelie. Die narratiewe benadering vra vir ander metafore as die vier waarna Long verwys, metafore wat meer in lyn is met die dominante metafoor van die postmoderne tyd, naamlik dié van 'n verskeidenheid van spieëls waarin idees weerkaats word.

Die idee van fiksieskryf wat verder in hierdie artikel ontplooi word, is onses insiens 'n voorbeeld van so 'n metafoor. Daarmee sluit ons aan by Walter Brueggemann (1989:3-4) se gebruik van die beeld van die poet. Hy is van mening dat waar die waarheid in vaste formules (proposisies) vasgevang word, dit wesenlik ' $n$ inkorting van die waarheid beteken. Daarteenoor stel hy poëtiese taal as:

... language that moves like Bob Gibson's fast ball, that jumps at the right moment, that breaks open old worlds with surprise, abrasion, and pace. Poetic speech is the only proclamation worth doing in a situation of reductionism, the only proclamation, I submit, that is worthy of the name preaching.

(Brueggemann 1989:3) 


\section{Prediking aan die hand van die metafoor van fiksieskryf}

Hierdie soort prediking is méér as morele of leerstellige onderrig, probleemoplossing, goeie advies of romantiese streling van die sinne. Dit is eerder prediking wat ons herinner dat God ons uitnooi om in sy Koninkryk te leef. Daarom vra dit dat ons baie versigtig met ons woorde sal omgaan, sodat dit nie as blote verdigsels of ontvlugting van die werklikheid beleef sal word nie. Die taak van die digter is om die gangbare sienings van die werklikheid te bevraagteken en nuwe moontlikhede vir die lewe oop te maak. Dit vra vir die waagmoed om 'n spesiale soort "fiksie" te skryf wat hierdie alternatiewe werklikheid sal oopmaak:

It is precisely the daring work of fiction to probe beyond settled truth and to walk to the edge of alternatives not yet available to us. It is this probe behind our settlements that makes newness possible. (...) The more tightly we hold to settled reality, the more likely the alternative construal of the poet will be dismissed as "mere fiction". The poet/prophet, however, does not flinch from "fiction," for the alternative envisioned in such speech is a proposal that destabilizes all our settled "facts," and opens the way for transformation and the gift of newness.

(Brueggemann 1989:5)

Om oor die preek te dink binne die metafoor van fiksieskryf, teenoor die metafoor van die getuie wat die "feite" moet spreek, maak 'n wêreld se verskil:

- Dit honoreer die meervoudige moontlikhede van verstaan van 'n bepaalde teks deur verskillende predikers en van die preek deur verskillende hoorders (wat Paul Ricoeur (1977:113) genoem het "die polisemiese aard van taal").

- Die doel van die preek is nie om finale waarhede oor te dra nie, maar nooi die hoorders om in 'n ervaring te deel.

- Teenoor die aansprake op die oordra van vaste en tydlose waarhede, lê die krag van die narratiewe benadering daarin dat die hoorders iets van hulle eie lewe in die spesifieke en eiesoortige van die Bybelse verhaal kan herken.

- Dit help die hoorders om hulle eie lewensverhaal te hersien aan die hand van die Groot Verhaal van God en die mense en die vraag te vra: "Hoe is my verhaal deel van hierdie Groot Verhaal?" 


\section{HOE PREEK MENS TE MIDDE VAN DIE METAFOOR VAN DIE DOOLHOF VAN SPIEËLS?}

Ons vind Anne Lamott se model vir fiksieskryf 'n bruikbare metode om reg te laat geskied aan die eise vir prediking, sonder om terug te val in die metafoor van die lamp (of getuie) wat die inherente lig het. In haar boek, wat handel oor die skryf van fiksie, Bird by Bird (Lamott 1995), ontwikkel sy die ABDCEmodel, aan die hand waarvan ons nou die preekmaakproses verder ontwikkel.

\subsection{Aksie (action)}

Ons stel voor dat die preek met die beskrywing van 'n aksie begin, wat dan, in aansluiting by Lowry (2001:30), geproblematiseer word. Sodoende word die beginpunt van die preek iets soortgelyk aan die begin van 'n verhaal waar 'n probleem of behoefte aan die orde gestel word wat later vanuit die Woord opgelos moet word. "Aksie" word hier in die wye sin van die woord gebruik: dit gaan oor 'n habitus wat alle kommunikatiewe handelinge insluit.

Om met 'n aksie te begin, beteken dat die preek uit die staanspoor aansluit by dinge wat besig is om te gebeur in die gemeenskap en waarmee mense hulle op verskillende maniere besig hou. Dit gaan oor sake waaroor daar gepraat word en waaroor daar in koerante en tydskrifte geskryf word. Dikwels word hierdie aksie in die kulturele uitinge van 'n gemeenskap bespeur: waaroor word daar flieks gemaak en wat is die temas in die nuutste boeke en teater? Dit kan iets baie plaaslik vanuit die gemeentelewe, die kerkjaar, die gemeenskap of die nuus wees. Maar dit kan ook groot geloofsvraagstukke wees soos die huidige debatte oor kernsake van die evangelie; of oor verdeeldheid in die kerk en hoe ons mekaar probeer verdra ten spyte van verskille; of oor die gemeenskap se moeite om effektief, maar Christelik met die misdaadsituasie om te gaan. Die belangrikste uitgangspunt is dat dit iets duidelik omskrewe moet wees wat vir mense herkenbaar is en waarmee hulle kan identifiseer.

Vir die prediker wat sy oor op die grond het en die hartklop van die samelewing voel, sal daar elke week 'n aksie wees waarby sinvol aangesluit kan word. Mense lewe immers, hulle doen dinge en praat oor dinge.

Lamott sê (1995:62): "You begin with action that is compelling enough to draw us in, make us want to know more."

\subsection{Agtergrond (background)}

Elke aksie speel af teen 'n agtergrond. Dinge gebeur nie maar net nie. Daar is 'n aanloop-storie. Daar is 'n rede waarom 'n sekere saak op die oomblik 'n kwessie is. In hierdie deel van die preek is die prediker veronderstel om sy/haar gehoor met hom/haar saam te neem en bietjie backtracking te doen. 


\section{Prediking aan die hand van die metafoor van fiksieskryf}

Wat is die historiese, sosiale en kulturele agtergrond wat in ag geneem moet word ten einde die aksie in perspektief te sien? Hoe het dit gekom dat hierdie saak tans op die voorgrond is en dat mense daaroor dink, wonder en praat? Wat is die geskiedenis van die aksie?

Lamott (1995:74) gebruik die beeld van die "designer for a play or a movie or story":

It may help you to know what the room (or ship or the office or the meadow) looks like where the action will take place. You want to know its feel, its temperature, its colors. Just as everyone is a walking advertisement for who he or she is, so every room is a little showcase of its occupants' values and personalities.

Die prediker moet as 't ware die kamer ontwerp en versier waarbinne die aksie wat belig word, afspeel. Die agtergrond, saam met die goeie beskrywing van die aksie, help die hoorders om met die saak te identifiseer en sodoende voel hulle in hulle bestaan aangespreek.

\subsection{Ontwikkeling (development)}

In 'n goeie preek vind 'n ontwikkeling van nuwe insigte plaas. Daar moet iets voor die oë van die mense ontvou. Hulle moet gelei word tot ' $n$ nuwe verstaan en dit kan ons alleen doen aan die hand van ons teks wat vars uitgelê en verstaan word. Dit is egter iets anders as die uitlê van 'n teks met 'n latere toepassing op 'n lineêre vlak. Dit is ook iets anders as om vooraf reeds die "oplossing" te hê en later net 'n teks te vind wat dit staaf (kapstokprediking). Dit beteken ook dat daar in die preek 'n spanningslyn ingebou moet wees, sodat die hoorder nie uit die staanspoor reeds weet wat die temas en boodskap is nie. Goeie ontwikkeling behels dat die prediker daarin slaag om die verbande tussen die konteks (aksie en agtergond) en die teks te ontgin. "... language .... that breaks open old worlds with surprise, abrasion, and pace" (Brueggemann 1989:3). Daarvoor is die volgende nodig:

- Die regte tekskeuse.

- Diepgang met die teks. Dit beteken daar moet deeglike eksegese plaasvind en daar moet so wyd as moontlik oor die teks gelees word.

- Sonder om die teks in 'n kunsmatige nuwe betekenis in te dwing, moet daar gesoek word na vars invalshoeke. Wanneer dit gebeur, ontvou daar'n nuwe tafereel voor die geestesoog van mense. 
- Hierdie hele proses van uitlê en konfrontasie met die teks moet so logies en duidelik as moontlik in die preek uiteengesit word.

Om hierdie ontwikkeling te beskryf, gebruik Lamott (1995:39) die wonderlike beeld van 'n Polaroid. Hoewel die digitale-geslag dalk nie meer die beeld sal verstaan nie, bly dit 'n wonderlike beskrywing vir dié wat nog kan onthou hoedat die Polaroid-kamera se foto voor jou oë op die dowwe grys papier al helder en helderder verskyn.

\subsection{Klimaks (climax)}

Die ontwikkelingsgedeelte moet uitloop op 'n a-ha-moment. Ons as predikers smag daarna dat die hoorders saam met ons juig oor 'n nuwe ontdekking wat gemaak is.

Dit kan alleen gebeur as dié moment goed bedink en beplan word. Die prediker moet in sy/haar voorbereiding in staat wees om te kan verwoord wat hy of sy graag wil sien as 'n a-ha-moment vir die hoorders. Wat is die nuwe insig wat hy of sy graag wil laat posvat? Die prediker moet hierdie nuwe insig vir hom/haarself in 'n sin of twee kan verwoord.

Müller (2001:69) skryf oor terapie en sê: "Both good writing and therapy moves on the edges of life, are interested in the essence of life and of relationships. Like the writer, the therapist doesn't bring God in from outside, he or she just discovers God in the writing and in the therapy." Dieselfde geld vir die prediking.

Volgens hierdie benadering word die klimaks in die preek nie bereik deur 'n oordonderende proklamering van God en sy teenwoordigheid nie, maar deur 'n sensitiewe fasilitering van 'n proses wat mense sal help om God te ontdek. Dit kan selfs gedoen word sonder om die naam van God so oorvloediglik te gebruik soos wat predikers soms geneig is om te doen. Dit is veel meer effektief om sagkens op die "edges of life" te beweeg. Daar maak mense hulle eie preke onder die geklank van die Woord en kan hulle begelei word om onder die suggesties van die verkondiging tot eie unieke klimakse te kom.

\subsection{Einde (ending)}

Die prediking is deel van 'n groter "skryfproses". Mense is heeltyd besig om hulle lewensverhale te skryf. Hulle stap nie in die kerk in as onbeskrewe, oop leie waarop die prediker na hartelus kan skryf nie. Inteendeel, hulle is almal reeds beskrewe. Hulle luister na die prediking en met 'n positiewe of negatiewe reaksie gebruik hulle dit om verder aan hulle eie stories te skryf. As die prediker daarin kan slaag om hulle weg te stuur met 'n uitnodiging tot 


\section{Prediking aan die hand van die metafoor van fiksieskryf}

verdere verantwoordelike skryf van hulle verhale, het hy/sy geslaag. Die einde moenie probeer om 'n deksel op alles te plaas nie, maar om 'n situasie te skep wat mense uitnooi en roep om verder te werk aan hulle eie verhale.

Die prediker moet die wyse waarop sy preek gaan eindig, noukeurig beplan. Die preek kan nie maar net stop nie, dit moet na 'n logiese en sinvolle einde opbou. Dit hoef nie melodramaties te wees nie, maar dit moet die mense op 'n plek laat waar hulle uitgedaag word om verder te dink of handel. Die einde moet méér wees as 'n samevattende slot, dit is eerder die oopmaak van 'n deur waarmee mense na die lewe beweeg.

Wat Müller (2001:69) oor die terapeut sê, is ewe veel van toepassing op die prediker: "To be a therapist, like being a writer, is to be able to dream for and with people." Lamott (1995:231) gebruik die beeld van die sandkasteel. Deel van jou sien die volgende brander kom en wanhoop. Jy dink die oseaan gaan die sandkasteel platvee. "Another part of us thinks we'll figure out a way to divert the ocean. This is what separates artists from ordinary people: the belief, deep in our hearts, that if we build our castles well enough, somehow the ocean won't wash them away. I think this is a wonderful kind of person to be."

Die prediker is veronderstel om onder die kunstenaars te tel - daardie mense wat teen alles in hoop. Daardie mense wat aanhou om met hulle woorde boodskappe te bou soos sandkastele. Daardie mense wat glo dat hulle sandkastele sal stand hou en ten minste vir die tyd wat dit bly staan betekenis sal hê. Gelowige profete wat nie moeg word om mense met die woorde van die evangelie te konfronteer en uit te nooi nie.

Laat ons voortgaan om Sondae in die erediens ons "sandkastele" met groot drome te bou!

\section{Literatuurverwysings}

Bosman, $L$ L 2001. 'n Narratiewe beskouing van die pastoraal-terapeutiese self in 'n postmoderne samelewing. DD-proefskrif, Universiteit van Pretoria.

Brueggemann, W 1989. Finally comes the poet: Daring speech for proclamation. Minneapolis, MN: Fortress.

De Kiewit, C 2007. Proclaiming the glory of God: A homiletical approach. PhD dissertation, University of Pretoria.

Gibbs, E \& Bolger, R K 2006. Emerging churches: Creating Christian communities in postmodern cultures. London: SPCK.

Habermas, J 1968. Knowledge and human interests. London: Heineman.

Immink, F G 2004. Homiletics: The current debate. IJPT 8, 89-121.

Jackelén, A 2003. Thinkpiece: Science and religion getting ready for the future.

Zygon 38(2), 209-228. 
Kearney, R [1988] 1998. The wake of imagination: Toward a postmodern culture. Reprinted. London: Routledge.

Long, T G 2005. The witness of preaching. 2nd ed. Louisville, KY: Westminster John Knox.

Lowry, E L 2001. The homiletical plot: The sermon as narrative art form. Louisville, KY: Westminster John Knox.

Müller, J 2001. Therapy as fiction writing. NGTT 42(1\&2), 64-70.

Mumby, D K 1997. Modernism, postmodernism, and communication studies: A rereading of an ongoing debate. Communication Theory 7(1), 1-28.

Nel, M 2001. Ek is die verskil: Die invloed van persoonlikheid in die prediking. Bloemfontein: CLF-uitgewers.

Ricoeur, P 1977. The rule of metaphor: Multi-disciplinary studies of the creation of meaning in language. London: Routledge \& Kegan Paul. 